\title{
MIR1208 wt Allele
}

National Cancer Institute

\section{Source}

National Cancer Institute. MIR1208 wt Allele. NCI Thesaurus. Code C118128.

Human MIR1208 wild-type allele is located in the vicinity of 8q24.21 and is approximately 70 bases in length. This allele, which encodes MIR1208 pre-miRNA, may be involved in gene silencing. 